DR ADRIANA APARECIDA SIVIERO-MIACHON (Orcid ID : 0000-0002-3001-0184)

DR HORACIO DOMENÉ (Orcid ID : 0000-0002-1969-9486)

Article type : 4 Original Article - Americas

\title{
Characterization of Four Latin-American Families Confirms Previous Findings and Reveals Novel Features of Acid-labile Subunit (ALS) Deficiency
}

Paula A. Scaglia*, Ana C. Keselman*, Débora Braslavsky*, Lucía C. Martucci*, Liliana M. Karabatas*, Sabina Domené*, Mariana L. Gutiérrez*, María G. Ballerini*, María G. Ropelato*, Angela Spinola-Castro†, Adriana A. Siviero-Miachon†, Juliana Saito Tartuci†, Sol Rodríguez Azrak*, Rodolfo A. Rey*, Héctor G. Jasper*, Ignacio Bergadá* and Horacio M. Domené*.

*Centro de Investigaciones Endocrinológicas "Dr. César Bergadá" (CEDIE) CONICET -FEI División de Endocrinología, Hospital de Niños “Ricardo Gutiérrez”, Buenos Aires, Argentina. †Division of Pediatric Endocrinology, Federal University of Sao Paulo, UNIFESP/EPM, Sao Paulo, Brazil.

\section{Correspondence:}

Horacio M. Domené, PhD

Laboratorio de Biología Molecular

Centro de Investigaciones Endocrinológicas “Dr. César Bergadá” (CEDIE)

CONICET - FEI - División de Endocrinología, Hospital de Niños Ricardo Gutiérrez

This article has been accepted for publication and undergone full peer review but has not been through the copyediting, typesetting, pagination and proofreading process, which may lead to differences between this version and the Version of Record. Please cite this article as doi: $10.1111 /$ cen. 13361

This article is protected by copyright. All rights reserved. 
Gallo 1330 - C1425EFD Buenos Aires

Tel. (+54-11) 4963-5931 int. 130 - Fax: (+54-11) 4963-5930

hdomene@cedie.org.ar - www.cedie.org.ar

Short Title: Novel Features of ALS Deficiency

Keywords: Short stature, Acid-labile Subunit deficiency, IGFALS, IGF-I

\section{Abstract}

Objective: ALS deficiency (ACLSD), caused by inactivating mutations in both IGFALS gene alleles, is characterized by marked reduction of IGF-I and IGFBP-3 levels associated to mild growth retardation. The aim of this study was to expand the known phenotype and genetic characteristics of ACLSD by reporting data from four index cases and their families.

Design: Auxological data, biochemical and genetic studies were performed in four children diagnosed with ACLSD and all available relatives.

Methods: Serum levels of IGF-I, IGFBP-3, ALS, and in vitro ternary complex formation (ivTCF) were determined. After sequencing the IGFALS gene, pathogenicity of novel identified variants was evaluated by in vitro expression in transfected $\mathrm{CHO}$ cells. ALS protein was detected in patients' sera and $\mathrm{CHO}$ cells conditioned media and lysates by Western immunoblot.

Results: Four index cases and four relatives were diagnosed with ACLSD. The following variants were found: p.Glu35Glyfs*17, p.Glu35Lysfs*87, p.Leu213Phe, p.Asn276Ser, p.Leu409Phe, p.Ala475Val, and p.Ser490Trp. ACLSD patients presented low IGF-I and low or undetectable levels of IGFBP-3 and ALS. Seven out of 8 patients did not form ivTCF.

This article is protected by copyright. All rights reserved. 
Conclusions: This study confirms previous findings in ACLSD, such as the low IGF-I and a more severe reduction in IGFBP-3 levels, and a gene-dosage effect observed in heterozygous carriers. In addition, father to son transmission (father compound heterozygous and mother heterozygous carrier), preservation of male fertility, and marginal ALS expression with potential involvement in preserved responsiveness to rhGH treatment, are all novel aspects, not previously reported in this condition.

\section{Introduction}

Acid-labile subunit deficiency (ACLSD) (OMIM \#615961), caused by inactivating mutations in both IGFALS gene alleles, is characterized by severely reduced circulating levels of IGF-I and IGFBP-3 associated to mild growth retardation (height -2 to -3 SDS). ${ }^{1}$ The condition is transmitted with an autosomal recessive pattern of inheritance in both consanguineous and non-consanguineous families. ${ }^{2}$ About 30 patients from diverse ethnic backgrounds have been reported worldwide. ${ }^{3,4,5,6}$ Because ALS is essential for the stability of ternary complex with IGF-I and IGFBP-3 (or IGFBP-5), ${ }^{7}$ the lack of this protein results in the absence of the 150-kDa complex in the circulation and the instability of IGF-I and IGFBP-3. ACLSD patients present a lack of response to the acute and chronic administration of recombinant human $\mathrm{GH}(\mathrm{rhGH})$, both in terms of height velocity acceleration and increase in IGF-I levels. ${ }^{1,3,8,9,10,11}$ Pubertal delay and insulin insensitivity, have been frequently reported. ${ }^{3}$

We evaluated the impact on height and on the IGF system of different IGFALS gene variants characterized in four families with ACLSD. The study of these families confirms previous findings such as a marked reduction in circulating levels of IGF-I, and a more severe

This article is protected by copyright. All rights reserved. 
reduction in IGFBP-3 levels, associated to mild growth impairment. Functional characterization for several of the IGFALS variants found in these patients has been previously reported. ${ }^{12,13}$ The effect of one combined variant, still unreported, on the synthesis and secretion of ALS by in vitro expression, was also evaluated.

\section{Subjects and Methods}

In the four index cases, clinical examination and routine laboratory analysis ruled out non-endocrinological causes of short stature. Evaluation of the GH-IGF axis revealed normal GH response to stimulation tests with low levels of IGF-I and low or undetectable IGFBP-3 and ALS levels. Evaluation of other pituitary axes was normal (Supplementary Table 1).

\section{Cases descriptions}

\section{Family 1}

The proband (IV-4, Figure 1), a 13.8-year-old prepubertal boy referred for growth retardation, was born at term (Supplementary Table 1), the fourth of nine siblings from consanguineous parents (first degree cousins) of short normal height (Table 1). He always grew slightly below the $3^{\text {rd }}$ percentile, but from the age of 12 years his growth velocity became markedly low. At 13.8 years, he presented a height of $134.7 \mathrm{~cm}(-2.65 \mathrm{SDS})$, a weight of $28.3 \mathrm{~kg}(-2.47 \mathrm{SDS})$ and a bone age of 12.8 
years for 13.3 years. At the age of 14.6 years (height $138.0 \mathrm{~cm},-2.97$ SDS, Tanner stage I -pubic hair 2, testicular volume $3 \mathrm{ml}-$ ), he was started on rhGH treatment (0.32 mg/kg.week). He was treated up to 18.1 years of age (height $154.3 \mathrm{~cm},-2.67$ SDS, bone age 15.5 years), attaining a height of $155.3 \mathrm{~cm}$ at the age of 18.6 years (Supplementary Figure 1).

\section{Family 2}

The index case (II-1, Figure 1) was a 5.0-year-old girl, born at term (Supplementary Table 1). She was the only child of non-related healthy parents of normal height (Table 1). Her height was within normal limits, slightly below her target height (TH -0.73) (Supplementary Figure 2). She presented a 46,XX karyotype, a delayed bone age (3.5 years), and a normal brain MRI.

\section{Family 3}

The index case was a 4.7-year-old boy (II-2, Figure 1). He was born at term (Supplementary Table 1), the second child of healthy, non-consanguineous parents of normal height (Table 1). At first evaluation, he presented a normal height (Table 1), 1.41 SD below TH. However, during an observation period of 3.2 years, he grew poorly, deteriorating his height from -1.67 to -2.36 SDS. At the age of 7.9 years he started rhGH treatment $(0.15 \mathrm{mg} / \mathrm{kg}$.week) for 8 months, improving his height velocity from 3.1 to 7.5 $\mathrm{cm} /$ year (height gain $0.40 \mathrm{SD}$ ). After 5 months, out of treatment, he received rhGH for another 7 months, with poor compliance, attaining a height of -1.92 SDS at the age of 9.7 years. (Supplementary Figure 3).

This article is protected by copyright. All rights reserved. 


\section{Family 4}

The index case (III-2, Figure 1), a 2.4-year-old boy, was referred for short stature evaluation (Table 1 and Supplementary Figure 4). He was born at 39 weeks of gestation, the second child from non-consanguineous parents (Supplementary Table 1). While his mother (II-8) and his 6-year old brother (III-1) presented normal height, his father (II-4) was also short (Table 1).

While families 1 and 4 were evaluated at the "Ricardo Gutiérrez" Children's Hospital (Buenos Aires, Argentina), families 2 and 3, both living in Brazil, were evaluated at Federal University of Sao Paulo, (Brazil). Other studies were all performed at the "Ricardo Gutiérrez" Children's Hospital. Auxological data, biochemical and genetic studies were also extended to all available relatives (Table 1).

The study was conducted in accordance with the Helsinki Declaration. The Ethics Committee of the "Ricardo Gutiérrez" Hospital approved the protocol. The patients gave their assent and parents and relatives signed a written informed consent for molecular studies.

\section{Endocrinological evaluation}

Serum levels of GH, IGF-I and IGFBP-3 and anti-thyroperoxidase antibodies were determined by chemiluminescent immunometric assays (Immulite 2000, Siemens Healthcare Diagnostics, Llamberis, Gwynedd, UK). TSH, free T4 (FT4), ACTH, cortisol, PRL, LH, $\mathrm{FSH}$, testosterone and insulin were measured by electrochemiluminescence (Cobas e411 This article is protected by copyright. All rights reserved. 
analyzer; Roche Diagnostics GmbH, Mannheim, Germany). Serum ALS levels were evaluated by enzyme-linked immunosorbent assay (ELISA, Mediagnost, Reutlingen, Germany). IGF-I response to exogenous rhGH was also evaluated (Supplementary Table 2).

\section{Molecular Studies:}

Genomic DNA was isolated as previously described. ${ }^{14}$ The IGFALS gene coding sequence was amplified by PCR as previously reported ${ }^{12}$ and sequenced in an $A B I 3730 x$ DNA analyzer (Macrogen Inc., Seoul, South Korea). Sequences were analyzed based on the following NCBI reference sequences: NG_011778.1 (gene), NM_004970.2 (mRNA) and NP_004961.1 (protein) by using the Mutation Surveyor Software v3.2 (State College, PA, USA).

Seventeen SNPs were characterized by sequencing IGFALS gene exons 1 and 2, intron 1, $950 \mathrm{bp}$ of 5 flanking region and $40 \mathrm{bp}$ of $3^{\prime}$ UTR. Only 9 informative SNPs were used to define a specific microhaplotype. Two STRs flanking the IGFALS gene locus, D16S3434 (21 Kb upstream) and D16S3024 (186 Kb downstream) were analyzed by PCR amplification using a fluorescently-labeled (FAM) primer, capillary electrophoresis and Genescan.

\section{Site-directed mutagenesis and transient transfection assays:}

Mutants ALS (p.Leu409Phe, pAla475Val and the double mutant p.[Leu409Phe;Ala475Val]-ALS) were generated into an expression vector containing the wild-type (WT) IGFALS cDNA (pCMV6-XL5-hIGFALS, Origene, Rockville, USA), using the Quick

Change II XL Site-Directed Mutagenesis Kit (Agilent Technologies, Santa Clara, CA, USA) as previously described. ${ }^{13}$

This article is protected by copyright. All rights reserved. 
Transfections were performed using Chinese hamster ovarian ( $\mathrm{CHO}$ ) cells as previously described and lysates and conditioned media (CM) were collected 48 hours after transfection for western immunoblot analysis. ${ }^{13}$

\section{In vitro ternary complex formation (ivTCF):}

In vitro ternary complex formation (ivTCF) was evaluated by size exclusion chromatography. In family 1, using a HiPrep 16/60 Sephacryl S-200HR column (Amersham Pharmacia Biotech AB, Uppsala, Sweden $)^{12}$ and in families 2, 3 and 4 ivTCF by using a HiLoad 16/600 Superdex 200 column (GE Healthcare, Bio-Sciencies AB, Uppsala, Sweden) as previously described. ${ }^{10,13}$

\section{Western immuno blot:}

ALS in serum samples and those produced by $\mathrm{CHO}$ cells in vitro, was evaluated by Western immunoblot (WIB) by using a goat anti-ALS antiserum (R\&D Systems, Inc. Minneapolis, MN, USA) as previously described. ${ }^{13}$

\section{Statistical analysis:}

Height, serum levels of IGF-I, IGFBP-3, and ALS, expressed as standard deviation score (SDS) were compared among ACLSD, heterozygous carriers (HC), and wild-type (WT) subjects by using Kruskal-Wallis test. In addition, median SDS values for each group were compared with the hypothetical zero values for the reference population by Wilcoxon signed rank test. Values of $\mathrm{P}<0.05$ were considered significant.

This article is protected by copyright. All rights reserved. 


\section{Results}

\section{Biochemical profile}

All index cases presented normal stimulated GH, low IGF-I, and extremely low or undetectable IGFBP-3 and ALS levels (Table 1, Supplementary table 1). Severe IGF-I deficiency with undetectable levels of IGFBP-3 and ALS was also found in four relatives: 2 siblings in family 1 (IV-3 and IV-8), the father (II-4) and the paternal aunt (II-5) in family 4 (Table 1 and Figure 1). IGF generation test was performed in index cases from families 2, 3 and 4 (Supplementary Table 2). Responses of IGF-I and IGFBP-3 to rhGH administration were low or absent. One father (II-4, family 4), presented a subnormal increase in IGF-I levels with no changes in either IGFBP-3 or ALS levels (Supplementary Table 2).

\section{Sequence analysis of the IGFALS gene}

Sequencing of the IGFALS gene revealed that all four index cases were either homozygous or compound heterozygous for a presumably pathogenic IGFALS gene variant (Table 1). Patient IV-4 from family 1 was homozygous for two different missense variants present in the same allele: c.[1225C>T;1424C>T], p. [Leu409Phe;Ala475Val]. While one of his older sisters (IV-3) and a younger brother (IV-8) were also homozygous for the same variants, his parents (III-2 and III-3), three sisters (IV-2, IV-5 and IV-6) and a brother (IV-7) were HC. Only the oldest sister (IV-1) was homozygous WT (Figure 1).

This article is protected by copyright. All rights reserved. 
In family 2, patient II-1 was compound heterozygous for a duplication (c.103dupG), predicting a frameshift mutation (p.Glu35Glyfs*17) and a missense variant (c.827A>G; p. Asn276Ser). The father was $\mathrm{HC}$ for the duplication and the mother, $\mathrm{HC}$ for the missense mutation (Figure 1).

Patient II-2 from family 3 was compound heterozygous for a deletion (c.103delG) predicting a frameshift mutation (p.Glu35Lysfs*87) and a missense variant (c.637C>T; p.Leu213Phe), while his parents were $\mathrm{HC}$, the father for the deletion and the mother for the missense mutation. The only sister was homozygous WT (Figure 1).

Family 4 presented a more complex mutational result: the patient (III-2) harbored two different heterozygous gene variants: a transition at c.1469C>G, predicting a missense point mutation (p.Ser490Trp); and a duplication (c.103dupG, p.Glu35Glyfs*17). The mother (II-8) was HC for the duplication (c.103dupG). The father (II-4) resulted compound heterozygous, with one allele carrying the c.1469C>G; p.Ser490Trp variant, and two different additional variants in the other allele: c.[1225C $>T ; 1424 C>T$, p.[Leu409Phe;Ala475Val]. The patient's brother was HC for the p.Ser490Trp variant. The study of the father's relatives, revealed that the grandmother (I-2) was HC for the p.[Leu409Phe;pAla475Val] and the grandfather (I-1) HC for the p.Ser490Trp variants. The younger uncle (II-6) was homozygous WT while a paternal aunt (II-5) turned out to present the same genotype as the father (Table1, Figure 1).

This article is protected by copyright. All rights reserved. 


\section{Gene dosage effect}

Height as well as IGF-I, IGFBP-3 and ALS were significantly different among ACLSD patients, HC and WT subjects. Although these parameters were only significantly lower in ACLSD compared to WT relatives, ACLSD and HC showed height, IGF-I, IGFBP-3, and ALS levels significantly below zero SDS, suggesting a gene dosage effect (Table 2).

\section{Western immunoblot (WIB)}

Serum ALS WIB (Figure 2, Panel A) showed that no 84- to 86-kD ALS protein band could be detected in three out of four index cases: IV-4 (family 1), II-1 (family 2) and III-2 (family 4), and in four of their relatives: IV-3 and IV-8 (family 1) and II-4 and II-5 (family 4), all of them homozygous or compound heterozygous for IGFALS variants. Patient II-2 (family 3) presented a faint but clear $84-86-\mathrm{kD}$ band indicating the presence of some ALS protein. Heterozygous carriers presented an $84-86-k D$ band less intense than that corresponding to a normal control.

In transfected CHO cells (Figure 2, Panel B), WIB revealed that WT-ALS was present mostly in the extracellular compartment $(\mathrm{CM})$ at 48 hours post-transfection, although a faint band of lower molecular weight was visible in the intracellular compartment, probably related to the lesser extent of glycosylation. While p.Ala475Val-ALS variant showed a similar pattern of expression as WT-ALS, no discernible band corresponding to ALS protein was observed in the $\mathrm{CM}$ or in the lysate of $\mathrm{CHO}$ cells transfected with either the p.Leu409PheALS variant or the double mutant p.[Leu409Phe;Ala475Val]-ALS variant, indicating that the lack of ALS in the patient could be attributed to the pathogenic effect of the p.Leu490Phe variant.

This article is protected by copyright. All rights reserved. 


\section{In vitro ternary complex formation (ivTCF)}

Profiles corresponding to ivTCF are shown in figure 3 . In family 1 , ivTCF was performed with the addition of $6 \mu \mathrm{g} / \mathrm{ml}$ rhIGFBP-3 on Sephacryl column. ${ }^{13}$ In subjects presenting ACLSD (IV-3, IV-4 and IV-8), no peak corresponding to the ternary complex was detected, with most of the complexed ${ }^{125}$ I-IGF-I eluting in the 50-kD peak corresponding to the binary complex formed with IGFBPs. Heterozygous carriers (III-1, III-2, IV-5, IV-6 and IV7) presented peaks corresponding to ternary and binary complex of similar magnitude, while the only homozygous WT subject from this family (IV-1) showed a predominant 150kD peak corresponding to the ternary complex.

In the other three families, ivTCF was performed on Superdex-200 columns. Patient II-1 (family 2) showed no detectable 150-kD peak and her parents had both a clear peak corresponding to ternary complexes. In family 3, patient II-2 presented a reduced but detectable ternary complex, while his parents and his older sister all presented predominant ternary complex peaks.

In family 4, size-exclusion chromatography revealed absence of $150-\mathrm{kD}$ peak in the three ACLSD subjects (III-2, II-4, and II-5) (Figure 3, panel A), whereas normal ternary complexes were observed in $\mathrm{HC}(\mathrm{I}-2, \mathrm{II}-8$, and III-1) as well as in the only homozygous WT subject from this family (II-6) (Figure 3, panel B).

This article is protected by copyright. All rights reserved. 


\section{IGFALS polymorphism analysis}

Given the unusual finding of two uncommon gene variants c. [1225C $>T ; 1424 C>T]$ in the same allele in families 1 and 4, a polymorphism analysis was undertaken to determine whether these two variants arose independently or they originated from a common ancestor. The analysis of 9 informative SNPs and two CA repeats (D16S3034 and D16S3024) revealed the common haplotyope $(C A)_{15}$ /acgaaccgt/(CA $)_{22}$ or $(C A)_{23^{\prime}}$ differing only by one CA-repeat in D16S3024, in all subjects carrying the c.[1225C $>T ; 1424 C>T$ ] double variant allele. This finding strongly suggests a founder effect for these variants, originated form a common ancestor (Table 3).

\section{Discussion}

In the present study, we have characterized ACLSD in four children presenting either short stature, normal stature but shorter than mid-parental height, or even normal height adequate to familial height. All cases presented normal GH-stimulated levels and severe IGFI and IGFBP-3 deficiencies. Despite this variable impact on postnatal growth, the lack of ALS had a consistent effect on the circulating IGF system resulting in diminished levels of IGF-I with a more severe reduction of IGFBP-3. ${ }^{3}$ The lack of ALS, resulting in the impairment of ivTCF, a landmark of this condition, was observed in 7 out of 8 ACLSD subjects in this study. Delayed puberty, frequently observed in ACLSD was present in the male index case of family 1 ( $4 \mathrm{ml}$ of testicular volume at the age of 15 years) and a relatively late thelarche in his older sister (11.5 years). The remaining ACLSD subjects were too young to characterize the time of puberty (three males of 3.0, 3.2 and 4.7 years old and a female 5.0 years old). Insulin resistance, a frequent finding in ACLSD, was not present in the index cases.

This article is protected by copyright. All rights reserved. 
From the original report in $2004,{ }^{1}$ at least 30 patients with complete ACLSD have been characterized..$^{3-6}$ In autosomal recessive genetic diseases, patients arise usually in consanguineous families being both parents carriers for the same pathogenic variants. However, in ACLSD more than $40 \%$ of the patients reported were compound heterozygous for two different variants inherited from non-related parents. ${ }^{2}$ This finding suggests that pathogenic IGFALS variants could be present in the general population, probably because they would not be under a strong negative selection pressure. Our previous finding of heterozygous inactivating IGFALS variants in idiopathic short stature and even in normal control children, support this interpretation. ${ }^{12}$ Reinforcing this observation, three out of four index cases from this study were compound heterozygous for different IGFALS gene variants, while their parents, obligate HC, were non-related. Only in family 1 the parents were first degree cousins, carrying the same genetic variants.

Characterization of two ACLSD undiagnosed siblings in family 1 , and the finding of two ACLSD adults in family 4, underline the importance to extend biochemical and genetic studies to all available relatives. Because ACLSD subjects could present a mild phenotype, it is not unusual to find undiagnosed ACLSD siblings and even adults. Family 4 represents the first example of father to son transmission of ACLSD, not due to an autosomal dominant pattern of inheritance, but because the proband was the offspring of a father compound heterozygous for two different pathogenic variants and a mother $\mathrm{HC}$ for another pathogenic variant in the IGFALS gene. Incidentally, this family revealed that male fertility is preserved in this condition. A situation that, associated to the mild phenotype and no evidence of a serious deleterious effect on health or lifespan, could explain the transmission of pathogenic IGFALS variants from one generation to another.

This article is protected by copyright. All rights reserved. 
The finding of two variants in cis (p.Leu409Phe and p.Ala475Val) in two non-related families of different ethnic background, opens the question as to the origin of this unusual variant combination. In family 1 , the two great-grand parents of the index case were Sephardic Jews from Aleppo, Syria, that migrated to Argentina at the beginning of the twentieth century. In family 4, the grandmother, carrier for these same variants, had Spanish ancestors. The finding of a similar haplotype with 9 intragenic SNPs and two flanking microsatellites suggests a gene-founder effect with likely a common ancestor from Spain. A similar finding of a common ancestor has been reported for the E180 splice variant in the GHR gene in patients with Laron syndrome from different countries. ${ }^{15}$

The auxological evaluation and the characterization of the IGF system in all 8 ACLSD subjects, $14 \mathrm{HC}$, and $3 \mathrm{WT}$ relatives revealed that $\mathrm{HC}$ for pathogenic IGFALS variants were 0.6 SD shorter than WT, presenting IGF-I, IGFBP-3 and ALS levels intermediate between ACLSD and WT relatives. A similar difference in height of 0.9 SD between $\mathrm{HC}$ and their WT relatives has been reported. ${ }^{2}$ However, these observations are limited by the relatively small number of WT subjects and due to the different ages among ACLSD patients, HC and WT subjects. These data confirm previous findings of a gene dosage effect of IGFALS gene on the IGF system, ${ }^{2,16}$ probably related to the requirement of a molar excess of ALS to stabilize circulating IGF-I in ternary complexes. ${ }^{7}$

This study also revealed the first subject (II-2, family 3) compound heterozygous for two pathogenic IGFALS variants retaining a marginal expression of ALS protein. While the p.Glu35Lysfs*87 (a pathogenic variant associated with complete ACLSD when present in homozygosis ${ }^{1}$ ) was not expressed in vitro, the novel p.Leu213Phe although partially This article is protected by copyright. All rights reserved. 
synthesized in vitro was not secreted. ${ }^{13}$ A similar effect on preserved synthesis but complete lack of secretion has been previously reported for the p.Asp440Asn-ALS variant, albeit for this particular variant a more pronounced intracellular accumulation was reported. ${ }^{17}$

Whether the finding of detectable levels of ALS in this patient, preserving the ability to form some ternary complexes, could be explained by marginal in vivo secretion of p.Leu213Phe-ALS, or alternatively, to some regression to the WT allele by a revertant mosaicism mechanism, ${ }^{18}$ remains to be elucidated. This marginal secretion of ALS protein may have practical implications. Previous studies have demonstrated a limited effect of rhGH treatment in ACLSD patients to improve adult height. ${ }^{3}$ The index case of family 1 (IV-4), had a very poor response to rhGH improving his height only 0.3 SDS after 3.5 years of rhGH treatment. The index case from family 3 (II-2) lost 0.72 SD from 4.7 to 7.8 years of age and gained 0.44 SD in 1.9 years receiving rhGH for only 1.25 years with partial compliance. In addition, measurements obtained 2 weeks after the last $\mathrm{rhGH}$ injection showed normalization of IGF-I levels ( $88 \mathrm{ng} / \mathrm{ml},-0.98 \mathrm{SDS})$ and measurable IGFBP-3 levels $(1.0 \mu \mathrm{g} / \mathrm{ml}$, -3.27 SDS). It could be speculated that this increase in IGF-I levels could be responsible for the observed growth acceleration.

Previously, we reported the impact of 7 different IGFALS variants found in these families by in vitro expression. ${ }^{13}$ Five of these variants (p.Glu35Lysfs*87, p.Glu35Glyfs*17, p.Asn276Ser, p.Ser490Trp and p.Leu409Phe) were not synthesized and secreted in vitro, confirming they all are pathogenic variants. Variant p.Leu213Phe retained some ability to be synthesized in vitro but with no evidence of secretion. Variant p.Ala475Val-ALS showed a similar pattern of expression as WT-ALS.

This article is protected by copyright. All rights reserved. 
Variants p.Leu409Phe and p.Ala475Val were found in the same allele both in homozygosis ( 3 subjects in family 1 ) or as compound heterozygous ( 3 subjects from family 4). To clarify the effect of these two variants on synthesis and secretion of ALS, they were expressed individually and combined. While variant p.Leu409Phe was not synthesized, variant p.Ala475Val preserved the ability to be synthesized and secreted. The double variant p.[Leu409Phe;Ala475Val] was not expressed in vitro, indicating that the pathogenicity of this double variant is caused by p.Leu409Phe variant.

In conclusion, this study not only confirms previous findings of ACLSD, but also reveals novel aspects such as: i) the first report of a father-to-son transmission, not as a consequence of an autosomal dominant pattern of inheritance (the father was compound heterozygous and the mother HC for different IGFALS variants); ii) male fertility is preserved in this condition; and iii) ACLSD children retaining some ALS expression, may increase IGF-I on rhGH treatment. Whether this might improve adult height, remains to be determined.

\section{Acknowledgement}

We are grateful to the children, parents and relatives who agreed to take part in this study.

\section{Disclosure statement}

The authors have nothing to disclose.

This article is protected by copyright. All rights reserved. 


\section{Funding}

Supported by PICT 2010 № 1916 (ANPCYT), PICT 2013 № 142 (FONCYT) and SANDOZ International $\mathrm{GmbH}$, Business Unit Biopharmaceuticals.

\section{References}

1. Domené, H. M. et al. Deficiency of the circulating insulin-like growth factor system associated with inactivation of the acid-labile subunit gene. N. Engl. J. Med. 350, 5707 (2004).

2. Fofanova-Gambetti, O. V et al. Impact of heterozygosity for acid-labile subunit (IGFALS) gene mutations on stature: results from the international acid-labile subunit consortium. J. Clin. Endocrinol. Metab. 95, 4184-91 (2010).

3. Domené, H. M. et al. Human acid-labile subunit deficiency: Clinical, endocrine and metabolic consequences. Horm. Res. 72, 129-141 (2009).

4. Schreiner, F., Schoenberger, S., Koester, B., Domené, H. M. \& Woelfle, J. Novel AcidLabile Subunit ( IGFALS ) Mutation p.T145K (c.434C>A) in a Patient with ALS Deficiency, Normal Stature and Immunological Dysfunction. Horm. Res. Paediatr. (2013). doi:10.1159/000355927

5. Hess, O. et al. A novel mutation in IGFALS, c.380T>C (p.L127P), associated with short stature, delayed puberty, osteopenia and hyperinsulinaemia in two siblings: insights into the roles of insulin growth factor-1 (IGF1). Clin. Endocrinol. (Oxf). 79, 838-844 (2013).

This article is protected by copyright. All rights reserved. 
6. Poukoulidou, T., Kowalczyk, J., Metherell, L., De Schepper, J. \& Maes, M. A Novel Homozygous Mutation of the IGFALS Gene in a Female Adolescent: Indirect Evidence for a Contributing Role of the Circulating IGF-I Pool in the Pubertal Growth Spurt. Horm. Res. Paediatr. 81, 422-427 (2014).

7. Boisclair, Y. R., Rhoads, R. P., Ueki, I., Wang, J. \& Ooi, G. T. The acid-labile subunit (ALS) of the $150 \mathrm{kDa}$ IGF-binding protein complex: An important but forgotten component of the circulating IGF system. J. Endocrinol. 170, 63-70 (2001).

8. Domené, H. M. et al. Phenotypic effects of null and haploinsufficiency of acid-labile subunit in a family with two novel IGFALS gene mutations. J. Clin. Endocrinol. Metab. 92, 4444-50 (2007).

9. Heath, K. E. et al. Primary Acid-Labile Subunit Deficiency due to Recessive IGFALS Mutations Results in Postnatal Growth Deficit Associated with Low Circulating Insulin Growth Factor (IGF)-I, IGF Binding Protein-3 Levels, and Hyperinsulinemia. J. Clin. Endocrinol. Metab. 93, 1616-1624 (2008).

10. van Duyvenvoorde, H. a. et al. Homozygous and heterozygous expression of a novel mutation of the acid-labile subunit. Eur. J. Endocrinol. 159, 113-120 (2008).

11. Fofanova-Gambetti, O. V et al. Three novel IGFALS gene mutations resulting in total ALS and severe circulating IGF-I/IGFBP-3 deficiency in children of different ethnic origins. Horm. Res. 71, 100-110 (2009).

12. Domené, H. M. et al. Heterozygous IGFALS Gene Variants in Idiopathic Short Stature and Normal Children: Impact on Height and the IGF System. Horm. Res. Paediatr. 80, 413-423 (2013).

13. Martucci, L. C. et al. Assessment of pathogenicity of natural IGFALS gene variants by This article is protected by copyright. All rights reserved. 
in silico bioinformatics tools and in vitro functional studies. Mol. Cell. Endocrinol. 429, 19-28 (2016).

14. Del Sal, G., Manfioletti, G. \& Schneider, C. The CTAB-DNA Precipitation Method: a simple common mini-scale preparation of template DNA from phagemids, phages or plasmids suitable for sequencing. Biotechniques 7, 514-518 (1989).

15. Gonçalves, F. T. et al. The E180splice mutation in the GHR gene causing Laron syndrome: Witness of a Sephardic Jewish exodus from the Iberian Peninsula to the New World? Am. J. Med. Genet. A 1-5 (2014). doi:10.1002/ajmg.a.36444

16. Högler, W. et al. IGFALS gene dosage effects on serum IGF-I and glucose metabolism, body composition, bone growth in length and width, and the pharmacokinetics of recombinant human IGF-I administration. J. Clin. Endocrinol. Metab. jc20133718 (2014). doi:10.1210/jc.2013-3718

17. Firth, S. M., Yan, X. \& Baxter, R. C. D440N mutation in the acid-labile subunit of insulin-like growth factor complexes inhibits secretion and complex formation. Mol. Endocrinol. 25, 307-14 (2011).

18. Biesecker, L. G. \& Spinner, N. B. A genomic view of mosaicism and human disease. Nat. Rev. Genet. 14, 307-20 (2013).

19. Ballerini, M. G. et al. Association of serum components of the GH-IGFs-IGFBPs system with GHR-exon 3 polymorphism in normal and idiopathic short stature children. Growth Horm. IGF Res. 23, 229-36 (2013).

20. Lejarraga, H., del Pino, M., Fano, V., Caino, S. \& Cole, T. J. [Growth references for weight and height for Argentinian girls and boys from birth to maturity: incorporation of data from the World Health Organisation from birth to 2 years and calculation of

This article is protected by copyright. All rights reserved. 
new percentiles and LMS values]. Arch. Argent. Pediatr. 107, 126-133 (2009).

21. 2000 CDC Growth Charts for the United States: Methods and Development

(https://www.cdc.gov/nchs/data/series/sr_11/sr11_246.pdf)

Table 1: Auxology, evaluation of the IGF system, and IGFALS genotype of the index cases and their relatives.

\begin{tabular}{|c|c|c|c|c|c|c|c|c|}
\hline \multirow{2}{*}{$\begin{array}{l}\text { Subject } \\
\text { (gender) }\end{array}$} & \multirow{2}{*}{$\begin{array}{l}\text { Age } \\
\text { (years) }\end{array}$} & \multirow{2}{*}{$\begin{array}{l}\text { Tanner } \\
\text { stage }\end{array}$} & \multirow{2}{*}{$\begin{array}{l}\text { Height } \\
\mathrm{cm} \\
\text { SDS }\end{array}$} & \multirow{2}{*}{$\begin{array}{l}\text { IGF-I } \\
\mathrm{ng} / \mathrm{ml} \\
\mathrm{SDS}\end{array}$} & \multirow{2}{*}{$\begin{array}{c}\text { IGFBP-3 } \\
\mu \mathrm{g} / \mathrm{ml} \\
\text { SDS }\end{array}$} & \multirow{2}{*}{$\begin{array}{c}\text { ALS } \\
\mathrm{mU} / \mathrm{ml} \\
\mathrm{SDS}\end{array}$} & \multicolumn{2}{|c|}{ IGFALS Genotype } \\
\hline & & & & & & & Allele 1 & Allele 2 \\
\hline & Family & & & & & & & \\
\hline $\begin{array}{l}\text { Father } \\
\text { III-2 }\end{array}$ & 41.0 & 5 & $\begin{array}{l}160.0 \\
-1.88\end{array}$ & $\begin{array}{c}98 \\
-0.91\end{array}$ & $\begin{array}{c}2.7 \\
-1.90\end{array}$ & $\begin{array}{l}1280 \\
-0.56\end{array}$ & $\begin{array}{c}\text { c. }[1225 \mathrm{C}>\mathrm{T} ; 1424 \mathrm{C}>\mathrm{T}] \\
\text { p. }[\mathrm{L} 409 \mathrm{~F} ; \mathrm{A} 475 \mathrm{~V}]\end{array}$ & WT \\
\hline $\begin{array}{l}\text { Mother } \\
\text { III-3 }\end{array}$ & 42.0 & 5 & $\begin{array}{l}157.0 \\
-0.61\end{array}$ & $\begin{array}{r}118 \\
-0.68\end{array}$ & $\begin{array}{c}3.1 \\
-1.60\end{array}$ & $\begin{array}{l}1468 \\
-0.55\end{array}$ & $\begin{array}{c}\text { c. }[1225 \mathrm{C}>\mathrm{T} ; 1424 \mathrm{C}>\mathrm{T}] \\
\text { p. }[\mathrm{L} 409 \mathrm{~F} ; \mathrm{A} 475 \mathrm{~V}]\end{array}$ & WT \\
\hline $\begin{array}{l}\text { IV-I } \\
\text { (F) }\end{array}$ & 19.0 & 5 & $\begin{array}{l}153.0 \\
-1.26\end{array}$ & $\begin{array}{r}233 \\
-1.66\end{array}$ & $\begin{array}{c}4.0 \\
-0.51\end{array}$ & $\begin{array}{l}3516 \\
1.40\end{array}$ & WT & WT \\
\hline $\begin{array}{l}\text { IV-2 } \\
\text { (F) }\end{array}$ & 17.0 & 4 & $\begin{array}{l}149.8 \\
-1.88\end{array}$ & $\begin{array}{l}92^{\mathrm{a}} \\
-1.69\end{array}$ & $\begin{array}{l}2.7^{\mathrm{a}} \\
-2.16\end{array}$ & $\begin{array}{l}1400^{\mathrm{a}} \\
-1.30\end{array}$ & $\begin{array}{c}\text { c. }[1225 \mathrm{C}>\mathrm{T} ; 1424 \mathrm{C}>\mathrm{T}] \\
\text { p. }[\mathrm{L} 409 \mathrm{~F} ; \mathrm{A} 475 \mathrm{~V}]\end{array}$ & WT \\
\hline (F) & 16.0 & 4 & $\begin{array}{l}143.5 \\
-2.69\end{array}$ & $\begin{array}{c}47 \\
-7.90\end{array}$ & $\begin{array}{l}<0.5 \\
<-3.50\end{array}$ & $\begin{array}{l}<100 \\
<-2.78\end{array}$ & $\begin{array}{c}\text { c. }[1225 \mathrm{C}>\mathrm{T} ; 1424 \mathrm{C}>\mathrm{T}] \\
\text { p. }[\mathrm{L} 409 \mathrm{~F} ; \mathrm{A} 475 \mathrm{~V}]\end{array}$ & $\begin{array}{c}\text { c. }[1225 \mathrm{C}>\mathrm{T} ; 1424 \mathrm{C}>\mathrm{T}] \\
\text { р. }[\mathrm{L409F} ; \mathrm{A} 475 \mathrm{~V}]\end{array}$ \\
\hline $\begin{array}{l}\text { IV-4 } \\
\text { (M) }\end{array}$ & 14.4 & 1 & $\begin{array}{l}136.2 \\
-2.76\end{array}$ & $\begin{array}{c}29 \\
-3.22\end{array}$ & $\begin{array}{l}<0.5 \\
<-4.30\end{array}$ & $\begin{array}{l}<100 \\
<-3.12\end{array}$ & $\begin{array}{c}\text { c. }[1225 \mathrm{C}>\mathrm{T} ; 1424 \mathrm{C}>\mathrm{T}] \\
\text { p. }[\mathrm{L} 409 \mathrm{~F} ; \mathrm{A} 475 \mathrm{~V}]\end{array}$ & $\begin{array}{c}\text { c. }[1225 \mathrm{C}>\mathrm{T} ; 1424 \mathrm{C}>\mathrm{T}] \\
\text { p. }[\mathrm{L409F} ; \mathrm{A} 475 \mathrm{~V}]\end{array}$ \\
\hline $\begin{array}{l}\text { IV-5 } \\
\text { (F) }\end{array}$ & 12.0 & 3 & $\begin{array}{l}144.5 \\
-0.68\end{array}$ & 229 & $\begin{array}{c}3.3 \\
-1.31\end{array}$ & $\begin{array}{l}1409 \\
-1.22\end{array}$ & $\begin{array}{c}\text { c. }[1225 \mathrm{C}>\mathrm{T} ; 1424 \mathrm{C}>\mathrm{T}] \\
\text { p. }[\mathrm{L409F} ; \mathrm{A} 475 \mathrm{~V}]\end{array}$ & WT \\
\hline IV-6 & 10.0 & 1 & 125.6 & 85 & 2.0 & 809 & c. $[1225 \mathrm{C}>\mathrm{T} ; 1424 \mathrm{C}>\mathrm{T}]$ & WT \\
\hline
\end{tabular}

This article is protected by copyright. All rights reserved. 


\begin{tabular}{|c|c|c|c|c|c|c|c|c|}
\hline (F) & & & -1.45 & -1.04 & -1.84 & -1.96 & p.[L409F;A475V] & \\
\hline $\begin{array}{l}\text { IV-7 } \\
\text { (M) }\end{array}$ & 6.0 & 1 & $\begin{array}{l}110.0 \\
-1.08\end{array}$ & $\begin{array}{c}87 \\
-0.17\end{array}$ & $\begin{array}{c}2.7 \\
-1.57\end{array}$ & $\begin{array}{l}990 \\
-1.27\end{array}$ & $\begin{array}{c}\text { c. }[1225 \mathrm{C}>\mathrm{T} ; 1424 \mathrm{C}>\mathrm{T}] \\
\text { p. }[\mathrm{L} 409 \mathrm{~F} ; \mathrm{A} 475 \mathrm{~V}]\end{array}$ & WT \\
\hline $\begin{array}{l}\text { IV-8 } \\
\text { (M) }\end{array}$ & 3.0 & 1 & $\begin{array}{l}87.6 \\
-1.46\end{array}$ & $\begin{aligned} &<25 \\
&<-2.65\end{aligned}$ & $\begin{array}{l}<0.50 \\
<-4.05\end{array}$ & $\begin{array}{l}<100 \\
<-3.13\end{array}$ & $\begin{array}{c}\text { c. }[1225 \mathrm{C}>\mathrm{T} ; 1424 \mathrm{C}>\mathrm{T}] \\
\text { p. }[\mathrm{L409F} ; \mathrm{A} 475 \mathrm{~V}]\end{array}$ & $\begin{array}{c}\text { c. }[1225 \mathrm{C}>\mathrm{T} ; 1424 \mathrm{C}>\mathrm{T}] \\
\text { p. }[\mathrm{L} 409 \mathrm{~F} ; \mathrm{A} 475 \mathrm{~V}]\end{array}$ \\
\hline $\begin{array}{l}\text { IV-9 } \\
\text { (F) }\end{array}$ & 0.9 & 1 & $\begin{array}{c}64 \\
-1.72\end{array}$ & N.A. & N.A. & N.A. & N.A. & N.A. \\
\hline
\end{tabular}

Family 2

\begin{tabular}{|c|c|c|c|c|c|c|c|c|}
\hline $\begin{array}{c}\text { Father } \\
\text { |-1 }\end{array}$ & 48 & 5 & $\begin{array}{l}178.0 \\
0.18\end{array}$ & $\begin{array}{c}147 \\
-0.12\end{array}$ & $\begin{array}{c}3.4 \\
-1.40\end{array}$ & $\begin{array}{l}1435 \\
0.06\end{array}$ & $\begin{array}{l}\text { c.103dupG } \\
\text { p.E35Gfs*17 }\end{array}$ & WT \\
\hline $\begin{array}{c}\text { Mother } \\
\text { I-2 }\end{array}$ & 44 & 5 & $\begin{array}{l}154.5 \\
-1.56\end{array}$ & $\begin{array}{l}170 \\
0.10\end{array}$ & $\begin{array}{c}3.4 \\
-1.40\end{array}$ & $\begin{array}{l}1335 \\
-0.90\end{array}$ & $\begin{array}{l}\text { c.827A>G } \\
\text { p.N276S }\end{array}$ & WT \\
\hline$(F)$ & 5.0 & 1 & $\begin{array}{l}99.5 \\
-1.28\end{array}$ & $\begin{aligned} &<25 \\
&<-2.60\end{aligned}$ & $\begin{array}{l}<0.5 \\
<-6.10\end{array}$ & $\begin{array}{l}<100 \\
<-3.18\end{array}$ & $\begin{array}{l}\text { c.103dupG } \\
\text { p.E35Gfs*17 }\end{array}$ & $c .827 A>G$ \\
\hline
\end{tabular}

Family 3

\begin{tabular}{|c|c|c|c|c|c|c|c|c|}
\hline $\begin{array}{l}\text { Father } \\
\text { I-1 }\end{array}$ & 40 & 5 & $\begin{array}{l}177 \\
0.03\end{array}$ & $\begin{array}{c}125 \\
-0.74\end{array}$ & $\begin{array}{c}2.7 \\
-2.20\end{array}$ & $\begin{array}{l}1008 \\
-1.64\end{array}$ & $\begin{array}{l}\text { c.103delG } \\
\text { p.E35Kfs*87 }\end{array}$ & WT \\
\hline $\begin{array}{l}\text { Mother } \\
\text { I-2 }\end{array}$ & 43 & 5 & $\begin{array}{c}160 \\
-0.63\end{array}$ & $\begin{array}{c}116 \\
-0.94\end{array}$ & $\begin{array}{c}2.9 \\
-2.00\end{array}$ & $\begin{array}{l}1071 \\
-1.57\end{array}$ & $\begin{array}{l}\text { c. } 637 \mathrm{C}>\mathrm{T} \\
\text { p.L213F }\end{array}$ & WT \\
\hline (F) & 7 & 1 & $\begin{array}{l}122 \\
0.09\end{array}$ & $\begin{array}{l}172 \\
1.38\end{array}$ & $\begin{array}{l}4.2 \\
1.58\end{array}$ & $\begin{array}{l}1651 \\
0.80\end{array}$ & WT & WT \\
\hline (M) & 4.7 & 1 & $\begin{array}{r}100 \\
-1.67\end{array}$ & $\begin{array}{c}35 \\
-3.50\end{array}$ & $\begin{array}{c}0.9 \\
-3.47\end{array}$ & $\begin{array}{l}227 \\
-2.84\end{array}$ & $\begin{array}{l}\text { c.103delG } \\
\text { p.E35Kfs*87 }\end{array}$ & $\begin{array}{l}\text { c.637C>T } \\
\text { p.L213F }\end{array}$ \\
\hline \multicolumn{9}{|c|}{ Family 4} \\
\hline $\begin{array}{l}\text { Father } \\
\text { II-4 }\end{array}$ & 30.4 & 5 & $\begin{array}{l}156.5 \\
-2.40\end{array}$ & $\begin{array}{c}25 \\
-7.94\end{array}$ & $\begin{array}{l}<0.5 \\
<-3.70\end{array}$ & $\begin{array}{l}<100 \\
<-5.28\end{array}$ & $\begin{array}{c}\text { c. }[1225 \mathrm{C}>\mathrm{T} ; 1424 \mathrm{C}>\mathrm{T}] \\
\text { p. }[\mathrm{L409F} ; \mathrm{A} 475 \mathrm{~V}]\end{array}$ & $\begin{array}{l}\text { c. } 1469 \mathrm{C}>\mathrm{G} \\
\text { p.S490W }\end{array}$ \\
\hline Mother & 25,8 & 5 & 162.3 & 128 & 2.6 & 800 & c.103dupG & WT \\
\hline
\end{tabular}

This article is protected by copyright. All rights reserved. 


\begin{tabular}{|c|c|c|c|c|c|c|c|c|}
\hline II-8 & & & 0.26 & -1.52 & -2.7 & -2.26 & p.E35Gfs*17 & \\
\hline $\begin{array}{l}\text { III-1 } \\
\text { (M) }\end{array}$ & 5,9 & 1 & $\begin{array}{l}116,5 \\
-0.60\end{array}$ & $\begin{array}{l}126 \\
0.12\end{array}$ & $\begin{array}{c}2.0 \\
-1.88\end{array}$ & $\begin{array}{l}700 \\
-1.90\end{array}$ & $\begin{array}{l}\text { c. } 1469 C>G \\
\text { p.S490W }\end{array}$ & WT \\
\hline $\begin{array}{l}\text { III-2 } \\
\text { (M) }\end{array}$ & 3.2 & 1 & $\begin{array}{l}88.6 \\
-2.30\end{array}$ & $\begin{array}{c}28 \\
-2.33\end{array}$ & $\begin{array}{l}<0.5 \\
<-4.05\end{array}$ & $\begin{array}{l}<100 \\
<-3.13\end{array}$ & $\begin{array}{l}\text { c.103dupG } \\
\text { p.E35Gfs*17 }\end{array}$ & $\begin{array}{l}\text { c. } 1469 \mathrm{C}>\mathrm{G} \\
\text { p.S490W }\end{array}$ \\
\hline $\begin{array}{l}\text { Aunt } \\
\text { (II-5) }\end{array}$ & 24.8 & 5 & $\begin{array}{r}153.0 \\
-1.26\end{array}$ & $\begin{array}{c}27 \\
-7.15\end{array}$ & $\begin{array}{l}<0.5 \\
<-4.60\end{array}$ & $\begin{array}{l}<100 \\
<-4.04\end{array}$ & $\begin{array}{c}\text { c. }[1225 \mathrm{C}>\mathrm{T} ; 1424 \mathrm{C}>\mathrm{T}] \\
\text { p. }[\mathrm{L} 409 \mathrm{~F} ; \mathrm{A} 475 \mathrm{~V}]\end{array}$ & $\begin{array}{l}\text { c. } 1469 \mathrm{C}>\mathrm{G} \\
\text { p.S490W }\end{array}$ \\
\hline $\begin{array}{l}\text { Uncle } \\
\text { (II-6) }\end{array}$ & 19.0 & 5 & $\begin{array}{l}172.3 \\
-0.05\end{array}$ & $\begin{array}{l}370 \\
1.11\end{array}$ & $\begin{array}{l}4.9 \\
0.27\end{array}$ & $\begin{array}{r}1452 \\
-1.33\end{array}$ & WT & WT \\
\hline $\begin{array}{c}\text { Grand- } \\
\text { mother } \\
(1-2)\end{array}$ & 56.5 & 5 & $\begin{array}{r}156.4 \\
-0.70\end{array}$ & $\begin{array}{l}133 \\
0.11\end{array}$ & $\begin{array}{l}2.7 \\
-2.0\end{array}$ & $\begin{array}{l}1044 \\
-1.64\end{array}$ & $\begin{array}{c}\text { c. }[1225 \mathrm{C}>\mathrm{T} ; 1424 \mathrm{C}>\mathrm{T}] \\
\text { p. }[\mathrm{L} 409 \mathrm{~F} ; \mathrm{A} 475 \mathrm{~V}]\end{array}$ & WT \\
\hline $\begin{array}{l}\text { Grand- } \\
\text { father } \\
\text { (I-1) }\end{array}$ & 59.7 & 5 & $\begin{array}{r}165.0 \\
-1.15\end{array}$ & $\begin{array}{r}106 \\
-0.93\end{array}$ & $\begin{array}{c}4.1 \\
-0.58\end{array}$ & $\begin{array}{r}798 \\
-2.41\end{array}$ & $\begin{array}{l}\text { c. } 1469 C>G \\
\text { p.S490W }\end{array}$ & WT \\
\hline
\end{tabular}

Serum IGF-I, IGFBP-3, and ALS levels are expressed as standard deviation score (SDS). ${ }^{19}$ For families 1 and 4 height SDS was based on Argentinean growth references, ${ }^{20}$ and for families 2 and 3 on CDC (2000), National Center for Health Statistics, Centers for Database Control and Prevention. ${ }^{21}$ an patient IV-2 from family 1 , biochemical profile was evaluated at the age of 22 years. Growth charts of ACLSD subjects are included in Supplementary Figures: subjects IV-4, IV-3 and IV-8 from family 1 as Supplementary Figures 1, 5 and 6, respectively; subject II-1 from family 2 as Supplementary Figure 2; subject II-2 from family 3 as Supplementary Figure 3; and subject III-2 from family 4 as Supplementary Figure 4. N.A.: not analyzed.

This article is protected by copyright. All rights reserved. 
Table 2: Height and IGF-I, IGFBP-3 and ALS levels in subjects with ALS deficiency (ACLSD), heterozygous carriers (HC), and wild type (WT).

\begin{tabular}{|c|c|c|c|c|}
\hline & $\begin{array}{l}\text { ACLSD } \\
(n=8)\end{array}$ & $\begin{array}{c}H C \\
(n=14)\end{array}$ & $\begin{array}{c}\text { WT } \\
(n=3)\end{array}$ & $\begin{array}{l}P \text { value } \\
\text { KW test }\end{array}$ \\
\hline $\begin{array}{l}\text { Age } \\
\text { (years) }\end{array}$ & $\begin{array}{c}9.7 \\
(3.0 \text { to } 30.4)\end{array}$ & $\begin{array}{c}40.5 \\
\text { (5.9 to } 59.7)\end{array}$ & $\begin{array}{c}19.0 \\
\text { (7.0 to } 19.0)\end{array}$ & 0.0329 \\
\hline Height & $\begin{array}{c}-1.99^{\mathrm{a}} \\
(-2.76 \text { to }-1.26)\end{array}$ & $\begin{array}{c}-0.69^{b} \\
(-1.88 \text { to } 0.26)\end{array}$ & $\begin{array}{c}-0.05 \\
(-0.70 \text { to } 0.09)\end{array}$ & 0.0019 \\
\hline IGF-I & $\begin{array}{c}-3.36^{\mathrm{c}} \\
(-7.94 \text { to }-2.33)\end{array}$ & $\begin{array}{c}-0.71^{\mathrm{c}} \\
(-1.69 \text { to } 0.12)\end{array}$ & $\begin{array}{c}1.11 \\
(-1.66 \text { to } 1.38)\end{array}$ & 0.0003 \\
\hline IGFBP-3 & $\begin{array}{c}-4.05^{c} \\
(-6.10 \text { to }-3.47)\end{array}$ & $\begin{array}{c}-1.86^{\mathrm{b}} \\
(-2.70 \text { to }-0.58)\end{array}$ & $\begin{array}{c}0.27 \\
(-0.51 \text { to } 1.58)\end{array}$ & $<0.0001$ \\
\hline ALS & $\begin{array}{c}-3.13^{\mathrm{c}} \\
(-5.28 \text { to }-2.78)\end{array}$ & $\begin{array}{c}-1.44^{b} \\
(-2.41 \text { to } 0.06)\end{array}$ & $\begin{array}{c}0.80 \\
(-1.33 \text { to } 1.40)\end{array}$ & 0.0002 \\
\hline
\end{tabular}

Results are expressed as median SDS (range) and groups were compared by Kruskal-Wallis (KW) test. Significant differences are given for comparison with the reference population (zero). ${ }^{\mathrm{a}} P<0.0001,{ }^{\mathrm{b}} P<0.001$, and ${ }^{\mathrm{c}} P<0.01$.

This article is protected by copyright. All rights reserved. 
Table 3: Characterization of SNPS and dinucleotide repeats at the IGFALS locus.

\begin{tabular}{|c|c|c|c|c|c|c|c|c|c|c|c|c|c|}
\hline \multirow[b]{2}{*}{ 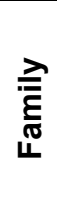 } & \multirow[b]{2}{*}{ 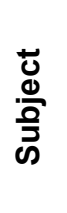 } & \multirow[b]{2}{*}{ 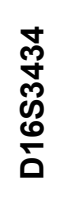 } & \multicolumn{5}{|c|}{ Promoter region } & \multicolumn{3}{|c|}{ Intron 1} & \multirow[b]{2}{*}{ 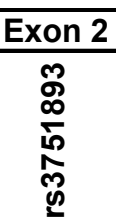 } & \multirow[b]{2}{*}{ 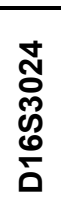 } & \multirow[b]{2}{*}{ IGFALS variant } \\
\hline & & & 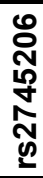 & 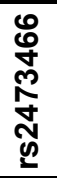 & 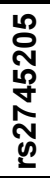 & 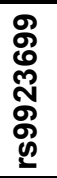 & 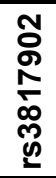 & 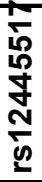 & 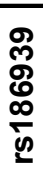 & 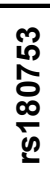 & & & \\
\hline \multirow{20}{*}{ 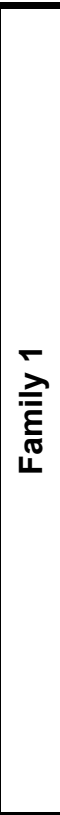 } & \multirow{2}{*}{ III-2 } & 15 & A & $\mathrm{C}$ & G & $\bar{A}$ & $\bar{A}$ & C & $\mathrm{C}$ & G & $\mathrm{T}$ & 23 & р. [L409F;A475V] \\
\hline & & 10 & $\bar{A}$ & $\mathrm{C}$ & $\mathrm{G}$ & $\bar{A}$ & $\bar{A}$ & $\mathrm{C}$ & $\mathrm{C}$ & $\bar{G}$ & $\mathrm{C}$ & 24 & WT \\
\hline & \multirow{2}{*}{ III-3 } & 15 & $\bar{A}$ & $\mathrm{C}$ & $G$ & $\bar{A}$ & $A$ & $\mathrm{C}$ & $\mathrm{C}$ & $G$ & $T$ & 23 & p.[L409F;A475V] \\
\hline & & 12 & $\mathrm{G}$ & $T$ & $\mathrm{C}$ & $G$ & $G$ & $T$ & $\bar{G}$ & $\mathrm{C}$ & $\mathrm{C}$ & 26 & WT \\
\hline & \multirow{2}{*}{ IV-1 } & 10 & $\bar{A}$ & $\mathrm{C}$ & $G$ & $\bar{A}$ & $\bar{A}$ & $\mathrm{C}$ & $\mathrm{C}$ & $\bar{G}$ & $\mathrm{C}$ & 24 & WT \\
\hline & & 12 & $\bar{G}$ & $T$ & $\mathrm{C}$ & G & $G$ & $T$ & $\mathrm{G}$ & $\mathrm{C}$ & $C$ & 26 & WT \\
\hline & \multirow{2}{*}{ IV-2 } & 15 & $\bar{A}$ & $\mathrm{C}$ & $\mathrm{G}$ & $\bar{A}$ & $\bar{A}$ & $\mathrm{C}$ & $\mathrm{C}$ & $\mathrm{G}$ & $T$ & 23 & $\mathrm{p}-[\mathrm{L} 409 \mathrm{~F} ; \mathrm{A} 475 \mathrm{~V}]$ \\
\hline & & 10 & $\bar{A}$ & $\mathrm{C}$ & $G$ & $A$ & $A$ & $C$ & $\mathrm{C}$ & $G$ & $\mathrm{C}$ & 24 & WT \\
\hline & \multirow{2}{*}{ IV-3 } & 15 & A & $\mathrm{C}$ & $\mathrm{G}$ & A & A & C & $\mathrm{C}$ & $G$ & $T$ & 23 & $\mathrm{p}$-[L409F;A475V] \\
\hline & & 15 & $\bar{A}$ & $\mathrm{C}$ & $\bar{G}$ & $\bar{A}$ & $\bar{A}$ & $\mathrm{C}$ & $\mathrm{C}$ & $\bar{G}$ & $T$ & 23 & p.[L409F;A475V] \\
\hline & \multirow{2}{*}{ IV-4 } & 15 & $\mathrm{~A}$ & $\mathrm{C}$ & $G$ & $\mathrm{~A}$ & $\mathrm{~A}$ & $\mathrm{C}$ & $\mathrm{C}$ & $\mathrm{C}$ & $T$ & 23 & p. [L409F;A475V] \\
\hline & & 15 & $\bar{A}$ & $\mathrm{C}$ & $\bar{G}$ & $\bar{A}$ & $\bar{A}$ & $\mathrm{C}$ & $\mathrm{C}$ & $\mathrm{C}$ & $T$ & 23 & p. [L409F;A475V] \\
\hline & \multirow{2}{*}{ IV-5 } & 15 & $\mathrm{~A}$ & $\mathrm{C}$ & $\mathrm{G}$ & $\mathrm{A}$ & $\mathrm{A}$ & $\mathrm{C}$ & $\mathrm{C}$ & $\mathrm{G}$ & $\mathrm{T}$ & 23 & p.[L409F;A475V] \\
\hline & & 12 & $\mathrm{G}$ & $\mathrm{T}$ & $\mathrm{C}$ & G & $G$ & $\mathrm{~T}$ & $G$ & $\mathrm{C}$ & $C$ & 26 & WT \\
\hline & \multirow{2}{*}{ IV-6 } & 15 & $\bar{A}$ & $\bar{C}$ & $\bar{G}$ & $\bar{A}$ & $\bar{A}$ & $\mathrm{C}$ & $\mathrm{C}$ & $\bar{G}$ & $T$ & 23 & р.[L409F;A475V] \\
\hline & & 12 & $\bar{G}$ & $T$ & $\mathrm{C}$ & G & $G$ & $T$ & $G$ & $\mathrm{C}$ & $\mathrm{C}$ & 26 & WT \\
\hline & \multirow{2}{*}{ IV-7 } & 15 & $\bar{A}$ & $\mathrm{C}$ & $\mathrm{G}$ & $\bar{A}$ & $\bar{A}$ & $\mathrm{C}$ & $\mathrm{C}$ & $\mathrm{G}$ & $\bar{T}$ & 23 & p.[L409F;A475V] \\
\hline & & 12 & $\mathrm{G}$ & $T$ & C & G & $\mathrm{G}$ & $\mathrm{T}$ & $G$ & $\mathrm{C}$ & $\mathrm{C}$ & 26 & WT \\
\hline & \multirow{2}{*}{ IV-8 } & 15 & A & $\mathrm{C}$ & G & $\bar{A}$ & A & $\mathrm{C}$ & $\mathrm{C}$ & $G$ & $T$ & 23 & p.[L409F;A475V] \\
\hline & & 15 & A & C & G & A & A & C & C & G & $T$ & 23 & p. [L409F;A475V] \\
\hline \multirow{16}{*}{ 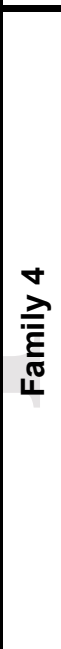 } & \multirow{2}{*}{ I-1 } & 14 & $\mathrm{G}$ & $T$ & $\mathrm{C}$ & $\bar{G}$ & $\bar{G}$ & $\mathrm{~T}$ & $\mathrm{G}$ & C & C & 25 & p.S490W \\
\hline & & 15 & $\bar{A}$ & $\mathrm{C}$ & $G$ & $A$ & $A$ & $\mathrm{C}$ & $\mathrm{C}$ & $G$ & $T$ & 31 & WT \\
\hline & \multirow{2}{*}{$\mathrm{I}-2$} & 15 & $\bar{A}$ & $\mathrm{C}$ & $\mathrm{G}$ & $\bar{A}$ & $\bar{A}$ & C & $\mathrm{C}$ & $\bar{G}$ & $T$ & 22 & р.[L409F;A475V] \\
\hline & & 13 & $\mathrm{G}$ & $T$ & C & $G$ & $\mathrm{G}$ & $T$ & $\mathrm{G}$ & C & $\mathrm{C}$ & 28 & $W T$ \\
\hline & \multirow{2}{*}{ II-4 } & 15 & $\bar{A}$ & $\mathrm{C}$ & $\mathrm{G}$ & $\bar{A}$ & $\bar{A}$ & $\mathrm{C}$ & $\mathrm{C}$ & $\bar{G}$ & $\bar{T}$ & 22 & р.[L409F;A475V] \\
\hline & & 14 & $\bar{G}$ & $T$ & $\bar{C}$ & $G$ & $G$ & $T$ & $\bar{G}$ & $\bar{C}$ & $\mathrm{C}$ & 25 & p.S490W \\
\hline & - & 15 & $\bar{A}$ & $\mathrm{C}$ & $G$ & $\bar{A}$ & $A$ & $\mathrm{C}$ & $\mathrm{C}$ & G & $T$ & 22 & p.[L409F;A475V] \\
\hline & $11-5$ & 14 & $\mathrm{G}$ & $\bar{T}$ & $\mathrm{C}$ & G & G & $T$ & $\mathrm{G}$ & $\mathrm{C}$ & $\mathrm{C}$ & 25 & p.S490W \\
\hline & . & 15 & $\mathrm{~A}$ & $\mathrm{C}$ & $G$ & A & $\mathrm{A}$ & $\mathrm{C}$ & $\mathrm{C}$ & $G$ & $T$ & 31 & WT \\
\hline & 11-6 & 13 & $\mathrm{G}$ & $T$ & $\mathrm{C}$ & $G$ & $\mathrm{G}$ & $\mathrm{T}$ & $G$ & $\mathrm{C}$ & C & 28 & WT \\
\hline & 118 & 12 & $\mathrm{G}$ & $\mathrm{T}$ & $C$ & G & $\mathrm{G}$ & $T$ & $G$ & $\mathrm{C}$ & $C$ & 21 & p.E35Gfs*17 \\
\hline & 11-8 & 12 & $\mathrm{G}$ & $T$ & $\mathrm{C}$ & $G$ & $\mathrm{G}$ & $T$ & G & $\mathrm{C}$ & $\mathrm{C}$ & 24 & WT \\
\hline & III-1 & 12 & $\mathrm{G}$ & $T$ & $\mathrm{C}$ & G & $\mathrm{G}$ & $T$ & $\mathrm{G}$ & $C$ & $C$ & 24 & WT \\
\hline & |II-1 & 14 & $\mathrm{G}$ & $T$ & $\mathrm{C}$ & $G$ & $\mathrm{G}$ & $\mathrm{T}$ & $\mathrm{G}$ & $C$ & $\mathrm{C}$ & 25 & p.S490W \\
\hline & & 12 & $\mathrm{G}$ & $T$ & $\mathrm{C}$ & $\mathrm{G}$ & $\mathrm{G}$ & $T$ & $G$ & $C$ & $C$ & 21 & p.E35Gfs*17 \\
\hline & 1II-2 & 14 & $\bar{G}$ & $\bar{T}$ & $C$ & $G$ & $G$ & $T$ & $\bar{G}$ & $\mathrm{C}$ & $C$ & 25 & p.S490W \\
\hline
\end{tabular}

We found 5 different alleles ranging from 10 to 15 CA-repeats for the D16S3034 microsatellite, while for the D16S3024 microsatellite, 8 different alleles ranging from 21 to 31 CA-repeats, were detected. All the individuals carriers for the p. [L409F;A475V] double variant allele present a similar haplotype: $(C A)_{15} /$ acgaaccgt/ $(C A)_{22}$ or $(C A)_{23}$ (shaded in grey).

This article is protected by copyright. All rights reserved. 


\section{Legends of figures:}

\section{Figure 1: Familial pedigrees}

Pedigree of the investigated families with ACLSD.

\section{Figure 2:}

\section{Serum Western immunoblot (WIB)}

Western immunoblot of serum samples using anti ALS antibody. Subjects are identified by using the same code as in the pedigrees in Figure 1. Marker (Mk) and normal control serum (C), respectively.

\section{ALS WIB of in vitro transient transfection experiments}

WIB of wild type (WT) and mutant-ALS proteins obtained by transient transfection of CHO cells. Samples of conditioned media (CM) and lysates (LYS) were chromatographed on SDSPAGE and immunoblotted for ALS. While p.L409F exhibits absence of expression indicating either a defect in synthesis and/or stability, the p.A475V shows similar expression in CM and LYS compared to WT. Expression of p.L409F;p.A475V double variant also denotes impaired synthesis and/or stability.

\section{Figure 3: In vitro ternary complex formation}

In vitro ternary complex formation (ivTCF) in serum samples previously incubated with ${ }^{125} \mathrm{I}$ IGF-I. In family 1, ivTCF was performed with the addition of $6 \mu \mathrm{g} / \mathrm{ml} \mathrm{rhIGFBP-3}$ on Sephacryl columns. In families 2, 3 and 4, ivTCF was performed on Superdex-200 columns. The 150 kDa peak corresponds to ternary complex (TC), the 30-50 kDa peak to binary complexes and the $7 \mathrm{kDa}$ peak to unbound ${ }^{125}$ I-IGF-I. Homozygous or compound heterozygous subjects are represented in red, WT subjects in black and HC in green, blue or purple. Family 4: A) ACLSD subjects (III-2, II-4, II-5), B) Heterozygous carriers (I-2, II-8 III-1) and wild type subject (II-6). Arrows indicate the positions of the molecular weight markers (150, 50 and $10 \mathrm{kDa})$.

This article is protected by copyright. All rights reserved. 

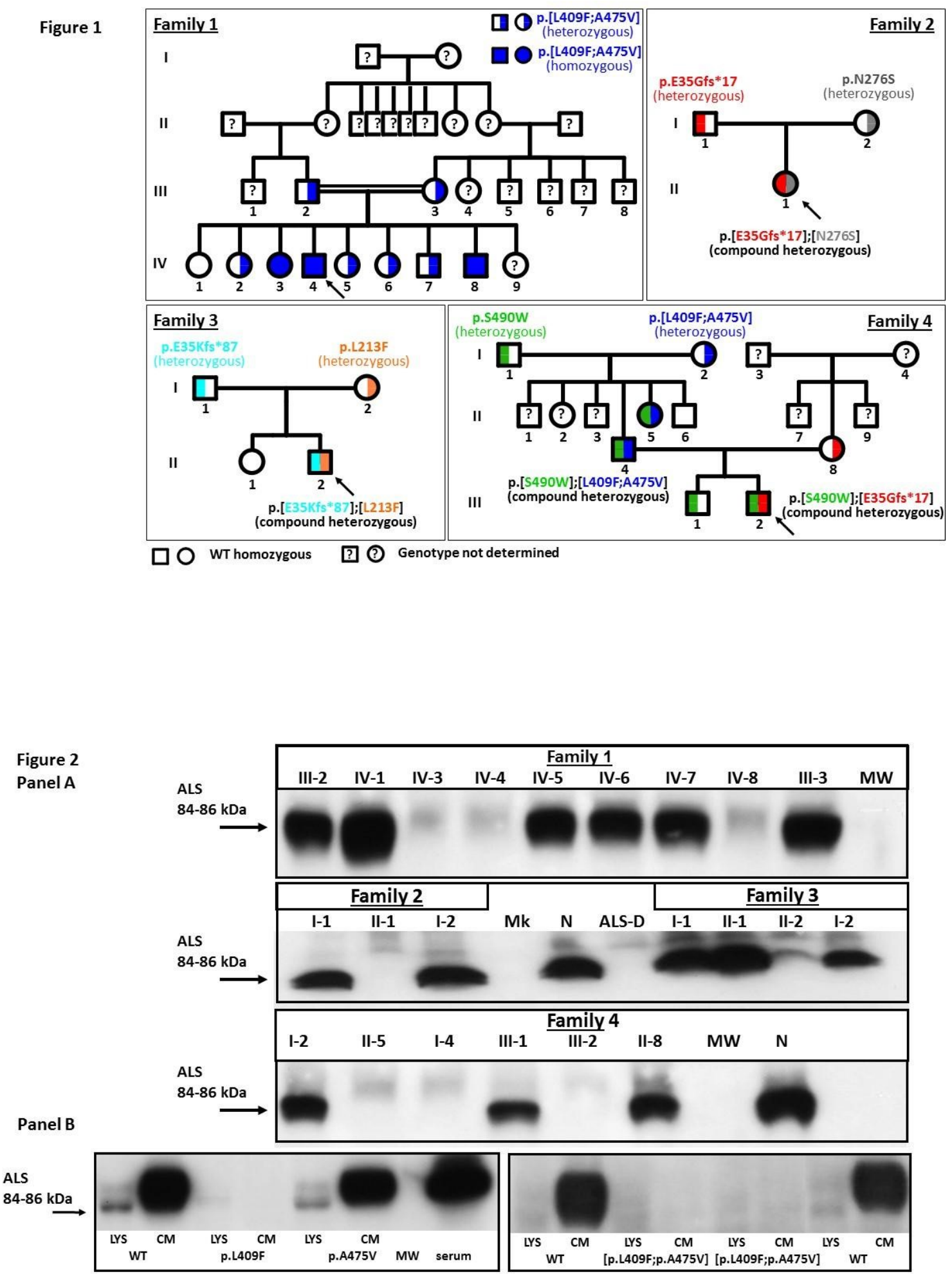

This article is protected by copyright. All rights reserved. 
Figure 3

Family 1

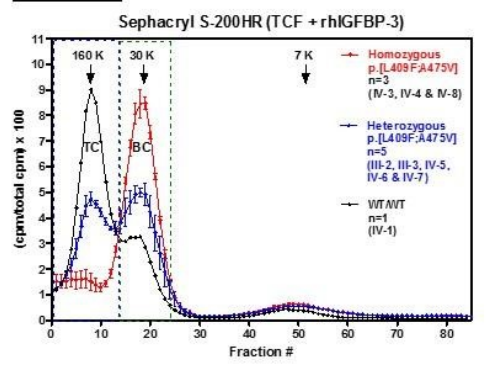

Family 2

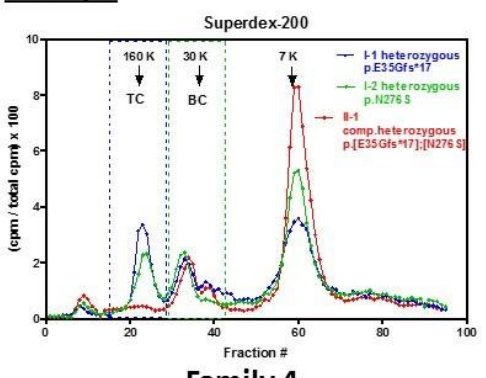

Family 3
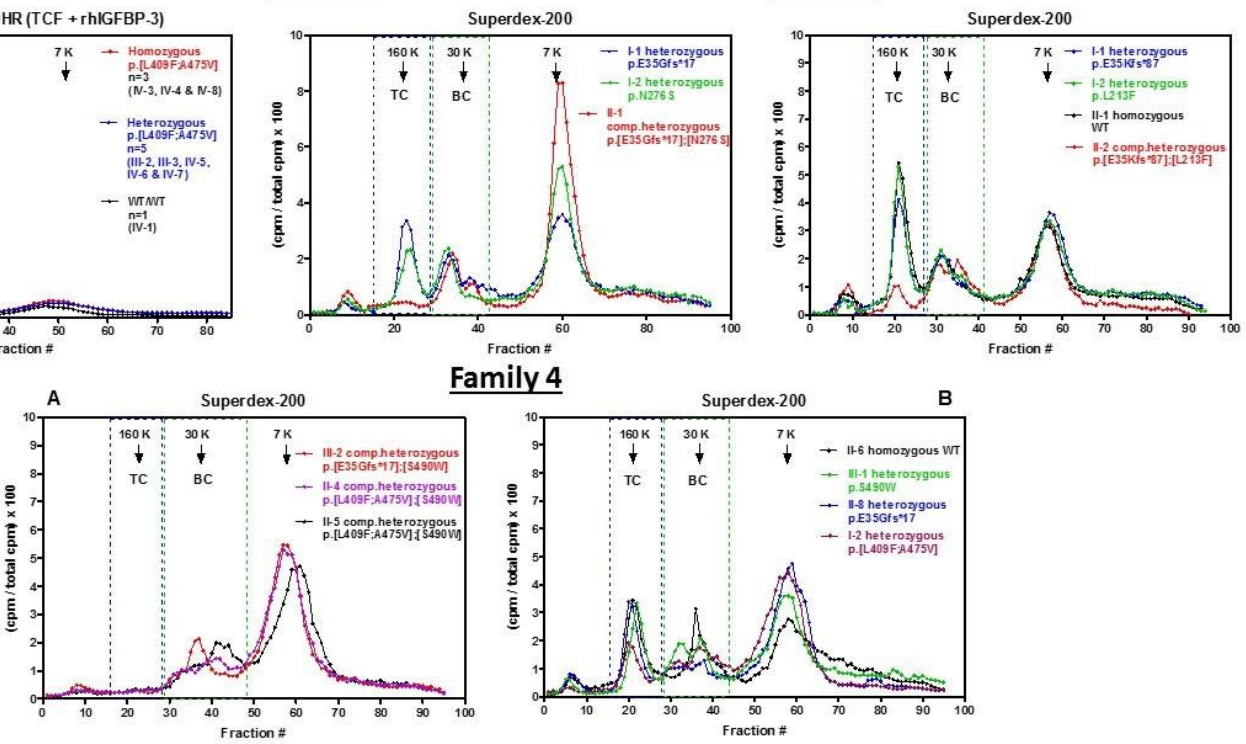

This article is protected by copyright. All rights reserved. 